\title{
Time to think on danger of Mobile Phone Radiation: Some evidences to support!
}

\author{
Patel VK' ${ }^{1}$ Patel $\mathbf{U}^{2}$, Patel NP3 \\ ${ }^{1}$ Dr Vishnu Kumar Patel, Assistant Professor (Surgery), S S Medical College, Rewa (MP), ${ }^{2}$ Dr Umesh Patel, Associate \\ Professor (Pediatrics), LN Medical College, Bhopal (MP), ${ }^{3}$ Dr Narmada Prasad Patel, Associate Professor (Medicine), LN \\ Medical College, Bhopal (MP), India
}

Address for Correspondence: Dr Vishnu Kumar Patel, Email: drvishnu.patel@gmail.com

\begin{abstract}
Mobile phone use has increased dramatically since its introduction in 1980's. The expanding use of this technology has been accompanied by concerns about health. Recently several expert groups critically reviewed the evidence on health effects of low-level exposure to radiofrequency (RF) electromagnetic fields.12 years back in October 2002, German physicians appealed to persons in the field of health care, politicians and the public with "great concern" claiming "soaring incidences of symptoms and diseases in the general population" to be causally related to the "commence of radio (wave) burden", i.e. due to mobile radio technology. Today his "great concern" has proved by many animal and human studies.
\end{abstract}

Key words: Mobile phone, electromagnetic energy, radiation injuries

\section{Introduction}

In recent years mobile phones have become very popular with adult and young people. As a tool of personal security and communication, its use has increased dramatically since its introduction in the early-to-mid 1980's. The expanding use of this technology has been accompanied by concerns about health. Public concern has been expressed regarding the possibility of adverse health effects related to radiofrequency (RF) electromagnetic energy (EME) emissions from mobile phones and their associated base stations.

In the late 1990s, several expert groups critically reviewed the evidence on health effects of low-level exposure to radiofrequency (RF) electromagnetic fields, and recommended research into the possible adverse health effects of mobile telephone use, especially after prolong use [1-5]. Parents become particularly anxious if their children are exposed to a presumed hazard that is unseen but which may have possible long-term harmful effects [6-9]. Some diseases and health conditions such as cancer, or severe and lingering pain and disability, are more feared than others [10]. Thus, even a small possibility of cancer, especially in children, from a potential hazard such as RF EME exposure receives significant public attention.

Manuscript received: $10^{\text {th }}$ May 2014

Reviewed: $25^{\text {th }}$ May 2014

Author Corrected: $20^{\text {th }}$ June 2014

Accepted for Publication: $29^{\text {th }}$ June 2014
Exposure to cell phone radiation occurs because cell phones emit radio frequencies ("RF"), a type of nonionizing electromagnetic energy that falls between FM radio waves and microwaves on the spectrum.

\section{Radiation Induced Genetic Damage}

Bioeffects are clearly established and occur at very low levels of exposure to electromagnetic fields and radiofrequency radiation. Bioeffects can occur in the first few minutes with cell and cordless phone use. Bioeffects can also occur from just minutes of exposure to mobile phone masts (cell towers), WI-FI, and wireless utility 'smart' meters that produce whole-body exposure. Chronic base station level exposures can result in illness.

Several thousand scientific studies over four decades point to serious biological effects and health harm from EMF and RFR. These studies report genotoxicity, singleand double-strand DNA damage, chromatin condensation, loss of DNA repair capacity in human stem cells, reduction in free-radical scavengers (particularly melatonin), abnormal gene transcription, neurotoxicity, carcinogenicity, damage to sperm

morphology and function, effects on behavior, and effects on brain development in the fetus of human mothers that use cell phones during pregnancy. 
Though cell phone radiation does not have the capacity to break chemical bonds in DNA, but recent studies shows that there is significant impact of DNA damage on prolong exposure to mobile phone radiation in animals as well as humane $[5,11,12,15]$, with damage not always being repaired by the cell.

Mutated cells are seen as a possible cause of cancer. On the other hand DNA carries the damage genetic material to next generation which leads to damage for future generation of cells. Studies also have shown that it does affect brain activity and may have other serious side effects linked to certain types of cancers $[10,13,14]$.

Recent studies show that cell phone radiation from prolonged cell phone use puts individuals at an increased risk for glioma, acoustic neuroma and meningioma. Because of the dangers of cell phone radiation, the World Health Organization ("WHO") reclassified cell phones as "possibly carcinogenic" to humans in May 2011.

\section{Animal Studies}

In one study, it was found that long-term exposure to mobile phone radiation leads to reduction in serum testosterone levels and cause hypospermatogenesis and maturation arrest in the spermatozoa in the testis of albino rats [16].

There are many new studies reporting sperm damage in humans and animals, leading to substantial concerns for fertility, reproduction and health of the offspring (unrepaired de novo mutations in sperm). Exposure levels are similar to those resulting from wearing a cell phone on the belt, or in the pants pocket, or using a wireless laptop computer on the lap. Sperm lack the ability to repair DNA damage.

Several international laboratories have replicated studies showing adverse effects on sperm count, motility, viability, morphology and pathology in men who use and particularly those who wear a cell phone, PDA or pager on their belt or in a pocket [17-24]. Animal studies have demonstrated oxidative and DNA damage, pathological changes in the testes of animals, decreased sperm mobility and viability, and other measures of deleterious damage to the male germ line [25].

There are fewer animal studies that have studied effects of cell phone radiation on female fertility parameters, egdecrease number of follicles, decrease ovary size, decrease ovarian development, premature cell dearth of ovarian follicles [26].

\section{Radiation \& Carcinogen effect}

There is a consistent pattern of increased risk of brain tumors (glioma and acoustic neuroma) associated with use of mobile phones and cordless phones[10,14]. Poulsen AH et al (2013), in their cohort study found that there is increased risk of skin cancers (basal cell carcinoma, squamous cell carcinoma and melanoma of head and neck) $[13,33]$. There is also increase incidence of childhood malignancies like leukemia [31] and salivary gland tumor (parotid gland tumor) [32].

Exposure to electromagnetic radiation (EMR) may increase breast cancer risk by inducing oxidative stress and suppressing the production of melatonin [34]. Mobile phone radiation can increase the risk of genital cancer. Watson JM et al (1998) in their in vitro study found that cancer cells from the steroid sex hormone regulated tissues of endometrium and prostate appeared to be more responsive to EMF than cells from ovarian cancers [35].

We need more studies of long term cell phone usage to better assess the cancer risk, but studies done till date clearly indicate "cancer culprit" in next few years. One study also shows that cell phone radiation may cause disturbance in immune system [37], but most of animal studies does not favor. There is strong epidemiologic evidence that exposure to EMF radiation is a risk factor for Alzheimer's disease [37].

Some positive health effects due to the exposure to the EMF radiation such as improve bone healing and reduce toxic effects of chemotherapy [36]

\section{Radiation \& Children}

Mobiles are used so widely by children now that most people assume they are safe. Because the use of mobiles by children is such a new phenomenon, scientists haven't studied it enough to be able to produce conclusive proof either way.

But ongoing research shows a link between mobile phone use and serious health risks and differences in children's anatomy make them significantly more vulnerable. There are many physiological factors that lead to higher radiation absorption rate and child has increased susceptibility to the effects of cell phone radiation:-

1. A smaller brain size

2. Their thinner skull bones allow for greater penetration of cell phone radiation.

3. Their brains hold more fluid, allowing for greater absorption of radiation 
Review Article

4. Radiation can enter all the way into their midbrain, where tumors are more deadly.

5. Children's cells reproduce more quickly, so they're more susceptible to aggressive cell growth.

6. Children's immune systems are also not as welldeveloped.

7. They face a far greater lifetime exposure.

Children are particularly vulnerable referring to the effect of microwaves from a mobile phone. The main effects are neurological, causing headaches, lack of concentration, memory loss, dizziness, fatigue, sleep disturbance and impaired hearing and vision, burning sensations or a heating around the ear. It can also cause epilepsy in children.

The American Academy of Pediatrics, in a letter to Congressman Dennis Kucinich dated 12 December 2012 states "Children are disproportionately affected by environmental exposures, including cell phone radiation. The differences in bone density and the amount of fluid in a child's brain compared to an adult's brain could allow children to absorb greater quantities of RF energy deeper into their brains than adults. It is essential that any new standards for cell phones or other wireless devices be based on protecting the youngest and most vulnerable populations to ensure they are safeguarded through their lifetimes".

\section{Effect on Pregnancy \& Fetus}

Fetal and neonatal exposures to cell phone radiation and wireless technologies in general may be a risk factor for hyperactivity, learning disorders and behavioral problems in school. Divan et al (2008) found that children born of mothers who used cell phones during pregnancy develop more behavioral problems and hyperactivity problem around age of school entry, had 25\% more emotional problems, 35\% more hyperactivity, $49 \%$ more conduct problems and $34 \%$ more peer problems [27].

One animal study also shows that cell phone exposure has been linked to altered fetal brain development and ADHD-like behavior in the offspring of pregnant mice [28]. Few studies also shows that there may be important link between electromagnetic radiation and autism [29]. With the continue increasing rate of autism and expected epidemic, public needs to know that these risks and transition to wireless from wire should not be presumed safe.

The blood brain barrier (BBB) is a protective barrier that prevents the flow of toxins into sensitive brain tissue. Increased permeability of the BBB caused by cell phone RFR may result in neuronal damage. Many research studies show that very low intensity exposures to RFR can affect the blood-brain barrier [30]. A single 2-hours exposure to cell phone radiation can result in increased leakage of the BBB, and 50 days after exposure, neuronal damage can be seen, and at the later time point also albumin leakage is demonstrated.

\section{How to reduce radiation Exposure}

It is very difficult to keep away own self from mobile and other electromagnetic radiation emitting devices, but by taking some precautions we decrease radiation damage. Experts agree you will reduce your exposure to radiation if you follow a few simple steps:-

1. Distance is your friend.

2. Don't hold a cell phone directly up to your head, hold it away from your head (at least $15 \mathrm{~mm}$ away from body).

3. Use a headset/ear piece or speakerphone to talk on the phone, or a nonmetal case that has been independently tested to reduce radiation up to 90 percent.

4. Text instead of calling

5. Don't use your phone when you have a weak signal

6. Don't put the phone to your ear until after the call connects

7. Don't put your phone in your pocket

8. Don't put your phone on your belt loop

9. Pregnant women should keep cell phones away from their abdomens, and men who wish to become fathers should never keep activated phones in their pockets.

10. Don't allow children to play with or use your cell phone, because they are most vulnerable to radiation.

11. Wireless laptops and other wireless devices should be strongly discouraged in schools for children of all ages.

12. Older children should use a headset or speakerphone when talking on a cell phone.

13. Do not text and drive, and use specially adapted antennas for cars to avoid absorbing maximum power as the phone moves from one cell system to another.

14. Turn off your wireless router at night to minimize exposure to radiation.

15. Eat green vegetables and get a good night's sleep in a dark room to enhance natural repair of DNA that may have been damaged by cell phone use.

You Can Protect Your Children!

The good news is that you can greatly reduce cell phone health risks to your children with "cell phone radiation 
protection". Simply attach an EarthCalm Quantum Cell to their phones, and they will be protected.

\section{Conclusion}

Today mobile phone is essential part of our life. Use of this technology has been accompanied by concerns about health. Though many studies shown clear-cut ill effect on health but other studies were non-conclusive. Due to the lack of any conclusive data related to adverse effect of long term use of mobile phones, limit exposure by reducing call time, by making calls where reception is good, by using hands-free devices or speaker options, or by texting keeping in mind that children are more prone for radiation injury.

\section{Funding: Nil}

\section{Conflict of interest: Nil}

\section{Permission from IRB: Yes}

\section{References}

1. Omura Y, Losco M. Electro-magnetic fields in the home environment (color TV, computer monitor, microwave oven, cellular phone, etc) as potential contributing factors for the induction of oncogen $\mathrm{C}$-fos $\mathrm{Ab} 1$, oncogen $\mathrm{C}$-fos $\mathrm{Ab} 2$, integrin alpha 5 beta 1 and development of cancer, as well as effects of microwave on amino acid composition of food and living human brain. Acupunct Electrother Res. 1993 Jan-Mar;18(1):3373.

2. Lebedeva NN, Sulimov AV, Sulimova OP, Kotrovskaya TI, Gailus T. Cellular phone electromagnetic field effects on bioelectric activity of human brain. Crit Rev Biomed Eng. 2000;28(1-2):32337

3. Santini R, Seigne M, Bonhomme-Faivre L. Danger of cellular telephones and their relay stations. Pathol Biol (Paris). 2000 Jul;48(6):525-8.

4. Wainwright P. Thermal effects of radiation from cellular telephones. Phys Med Biol. 2000 Aug;45(8):2363-72.

5. Malyapa RS, Ahern EW, Straube WL, Moros EG, Pickard WF, Roti Roti JL. Measurement of DNA damage after exposure to electromagnetic radiation in the cellular phone communication frequency band (835.62 and 847.74 MHz). Radiat Res. 1997 Dec;148(6):618-27.
6. Sudan M, Kheifets L, Arah OA, Olsen J. Cell phone exposures and hearing loss in children in the Danish National Birth Cohort. Paediatr Perinat Epidemiol. 2013 May;27(3):247-57.

7. Byun YH, Ha M, Kwon HJ, Hong YC, Leem JH, Sakong J, Kim SY, Lee CG, Kang D, Choi HD, Kim N. Mobile phone use, blood lead levels, and attention deficit hyperactivity symptoms in children: a longitudinal study. PLoS One. 2013;8(3):e59742

8. Valentini E, Ferrara M, Presaghi F, De Gennaro L, Curcio G. Republished review: systematic review and meta-analysis of psychomotor effects of mobile phone electromagnetic fields. Postgrad Med J. 2011 Sep;87(1031):643-51

9. Thomas S, Benke G, Dimitriadis C, Inyang I, Sim MR, Wolfe R, Croft RJ, Abramson MJ. Use of mobile phones and changes in cognitive function in adolescents. Occup Environ Med. 2010 Dec;67(12):861-6

10. Elwood JM. Epidemiological studies of radio frequency exposures and human cancer. Bioelectromagnetics. 2003;Suppl 6:S63-73.

11. Ozgur E, Guler G, Kismali G, Seyhan N. Mobile Phone Radiation Alters Proliferation of Hepatocarcinoma Cells. Cell Biochem Biophys. 2014 May 11. [Epub ahead of print]

12. Vijayalaxmi, Prihoda TJ. Genetic damage in human cells exposed to non-ionizing radiofrequency fields: a meta-analysis of the data from 88 publications (19902011). Mutat Res. 2012 Dec 12; 749(1-2):1-16.

13. Poulsen AH, Friis S, Johansen C, Jensen A, Frei $\mathrm{P}$, Kjaear SK, Dalton SO, Schüz J. Mobile phone use and the risk of skin cancer: a nationwide cohort study in Denmark. Am J Epidemiol. 2013 Jul 15;178(2):190-7

14. Corle C, Makale M, Kesari S. Cell phones and glioma risk: a review of the evidence. J Neurooncol. 2012 Jan;106(1):1-13.

15. Schuz J, Waldemar G, Olsen JH, Johanson C. Risk for the Central Nervous System disease among the Mobile Phone Subscribers: A Danish Retrospective Cohort Study. PLoS ONE. 2009; 4(2): e4389.

16. Meo SA, Arif M, Rashied S, Khan MM, Vohra MS, Usmani AM, Imran MB, Al-Drees AM Hypospermatogenesis and spermatozoa maturation arrest 
in rats induced by mobile phone radiation. J Coll Physicians Surg Pak. 2011 May;21(5):262-5.

17. Agarwal A, Deepinder F, Sharma RK, Ranga G, Li J. Effect of cell phone usage on semen analysis in men attending infertility clinic: an observational study. Fertil Steril. 2008 Jan;89(1):124-8.

18. Vignera SL, Condorelli RA, Vicari E, D'Agata R, Calogero AE. Effects of the exposure to mobile phones on male reproduction: a review of the literature. J Androl. 2012;33:350-6.

19. Sajeda S, Al-Watter Y. Effect of mobile phone usage on semen analysis in infertile men. Tikrit J Pharm Sci. 2011;7:77-82.

20. Agarwal A, Desai NR, Makker K, Varghese A, Mouradi R, Sabanegh E, Sharma R. (2009). Effects of radiofrequency electromagnetic waves (RF-EMW) from cellular phones on human ejaculated semen: an in vitro pilot study. Fertil Steril. 2009 Oct;92(4):1318-25.

21. DeIuliis GN, Newey RJ, King BV, Aitken RJ. Mobile phone radiation induces reactive oxygen species production and DNA damage in human spermatozoa in vitro. PLoS One. 2009 Jul 31;4(7):e6446.

22. Erogul O, Oztas E, Yildirim I, Kir T, Aydur E, Komesli G, Irkilata HC, Irmak MK, Peker AF. Effects of electromagnetic radiation from a cellular phone on human sperm motility: an in vitro study. Arch Med Res. 2006 Oct;37(7):840-3.

23. Falzone N, Huyser C, Becker P, Leszczynski D, Franken DR. The effect of pulsed 900-MHz GSM mobile phone radiation on the acrosome reaction, head morphometry and zona binding of human spermatozoa. Int J Androl. 2011 Feb;34(1):20-6.

24. Wdowiak A, Wdowiak L, Wiktor H. Evaluation of the effect of using mobile phones on male fertility. Ann Agric Environ Med. 2007;14(1):169-72.

25. Liu C, Gao P, Xu SC, Wang Y, Chen $\mathrm{CH}$, He MD, Yu ZP, Zhang L, Zhou Z. Mobile phone radiation induces mode-dependent DNA damage in a mouse spermatocytederived cell line: a protective role of melatonin. Int J Radiat Biol. 2013 Nov;89(11):993-1001

26. Gul A, Celebi H, Uğraş S The effects of microwave emitted by cellular phones on ovarian follicles in rats. Arch Gynecol Obstet. 2009 Nov;280(5):729-33.
27. Divan HA, Kheifets L, Obel C, Olsen J.Prenatal and postnatal exposure to cell phone use and behavioral problems in children. Epidemiology. 2008 Jul;19(4):5239.

28. Aldad TS, Gan G, Gao X, Taylor HS. Fetal Radiofrequency Radiation Exposure From 800-1900 Mhz-Rated Cellular Telephones Affects Neurodevelopment and Behavior in Mice. Sci. Rep. 2012; 312(2);1-7.

29. Thornton IM. Out of time: a possible link between mirror neurons, autism and electromagnetic radiation. Med Hypotheses. 2006;67(2):378-82.

30. Nittby H, Grafström G, Eberhardt JL, Malmgren L, Brun A, Persson BR, Salford LG. Radiofrequency and extremely low-frequency electromagnetic field effects on the blood-brain barrier. Electromagn Biol Med. 2008;27(2):103-26.

31. Li CY, Liu CC, Chang YH, Chou LP, Ko MC. A population-based case-control study of radiofrequency exposure in relation to childhood neoplasm. Sci Total Environ. 2012 Oct 1;435-436:472-8.

32. Söderqvist F, Carlberg M, Hardell L Use of wireless phones and the risk of salivary gland tumours: a casecontrol study. Eur J Cancer Prev. 2012 Nov;21(6):576-9.

33. Feychting M, Ahlbom A, Kheifets L. EMF and health. Annu Rev Public Health. 2005;26:165-89.

34. Naziroğlu M, Tokat S, Demirci S. Role of melatonin on electromagnetic radiation-induced oxidative stress and $\mathrm{Ca} 2+$ signaling molecular pathways in breast cancer. Recept Signal Transduct Res. 2012 Dec;32(6):290-7.

35. Watson JM, Parrish EA, Rinehart CA. Selective potentiation of gynecologic cancer cell growth in vitro by electromagnetic fields. Gynecol Oncol. 1998 Oct;71(1):64-71

36. Johnson MT, Vanscoy-Cornett A, Vesper DN, Swez JA, Chamberlain JK, Seaward MB, Nindl G. Electromagnetic fields used clinically to improve bone healing also impact lymphocyte proliferation in vitro. Biomed Sci Instrum. 2001; 37 :215-20.

37. Johansson O. Disturbance of the immune system by electromagnetic fields-A potentially underlying cause for 
Review Article

cellular damage and tissue repair reduction which could lead to disease and impairment. Pathophysiology. 2009 Aug;16(2-3):157-77.
38. Zur Nieden A, Dietz C, Eikmann T, Kiefer J, Herr CE. Physicians appeals on the dangers of mobile communication--what is the evidence? Assessment of public health data. Int J Hyg Environ Health. 2009 Nov;212(6):576-87.

\section{How to cite this article?}

Patel VK, Patel U, Patel NP. Time to think on danger of Mobile Phone Radiation: Some evidences to support! Int J Med Res Rev 2014;2(4):373-378. doi:10.17511/ijmrr.2014.i04.06 